\title{
VALIDASI BATAS ATAS BATAS BAWAH ESTIMASI DURASI GEDUNG KONSTRUKSI BERTINGKAT BERBASIS EARNED SCHEDULE
}

\author{
Catherine Michellie Widjaja ${ }^{1}$, Basuki Anondho² \\ ${ }^{1}$ Program Studi Sarjana Teknik Sipil, Universitas Tarumanagara Jakarta \\ Email: catherine.325160142@stu.untar.ac.id \\ ${ }^{2}$ Program Studi Sarjana Teknik Sipil, Universitas Tarumanagara Jakarta \\ Email: basukia@ft.untar.ac.id
}

Masuk : 29-07-2020, revisi: 02-03-2021, diterima untuk diterbitkan : 07-03-2021

\begin{abstract}
ABSTRAK
Penentuan estimasi penyelesaian proyek merupakan kegiatan yang berpengaruh dalam proses perencanaan karena dapat menentukan keberhasilan atau kegagalan proyek tersebut. Namun, durasi seringkali tidak sesuai dengan prediksi karena sifat ketidakpastian proyek. Perhitungan dengan metode probabilistik dinilai lebih baik daripada deterministik karena metode ini menyertakan unsur ketidakpastian dalam perhitungannya. Disamping itu, perhitungan probabilistik menyajikan hasil dalam bentuk interval yang dinyatakan dalam batas atas dan batas bawah. Dalam memprediksi durasi akhir proyek, metode Earned Schedule (ES) yang berbasis waktu dinilai mampu mengatasi kekurangan Earned Value (EV) yang berbasis biaya. Penelitian ini bertujuan untuk menetapkan nilai prediksi batas atas dan batas bawah proyek yang sedang berjalan dengan metode ES melalui validasi terhadap durasi nyata proyek yang sudah selesai. Rata-rata prediksi durasi proyek konstruksi yang sedang berjalan dihitung menggunakan metode ES dengan bantuan Microsoft Excel. Hasilnya kemudian divalidasi terhadap rata-rata durasi nyata proyek yang sudah selesai menggunakan uji hipotesis rata-rata sampel ganda. Hasil nilai batas atas proyek yang sedang berjalan dinyatakan valid dan nilai batas bawah dinyatakan tidak valid dengan nilai batas atas sebesar $0,0025 \mathrm{minggu} / \mathrm{m}^{2}$ dan batas bawah $0,0020 \mathrm{minggu} / \mathrm{m}^{2}$.
\end{abstract}

Kata Kunci: estimasi durasi; probabilistik; Earned Schedule; validasi; batas atas dan batas bawah.

\begin{abstract}
Determination of estimated project completion is an activity that influenced the planning project since it can decide the success or failure of the project. However, duration is often not in accordance with prediction caused by uncertainty of the project. Calculation by probabilistic method is rated better than deterministic since probabilistic includes the uncertainty factor in its calculation. In addition, probabilistic method provides results in the form of intervals in upper to lower limit. In predicting project's final duration, the time-based Earned Schedule (ES) method is rated capable of overcoming the lack of cost-based Earned Value (EV). This research aims to determine the ongoing project's upper and lower limit prediction duration using ES method through validation towards the completed project's real duration. The average prediction of ongoing project duration will be calculated using ES by Microsoft Excel. The results will be validated towards the average real project duration using hypothesis tests of two independent population means. Result of average of upper limits indicates a valid value while the average of lower limits indicates a non-valid value with the upper limit value is 0.0025 week $/ \mathrm{m}^{2}$ and lower limit is 0.0020 week $/ m^{2}$
\end{abstract}

Keywords: duration estimation; probabilistic; Earned Schedule; validation; upper limit and lower limit.

\section{PENDAHULUAN}

\section{Latar Belakang}

Keberhasilan proyek salah satunya tergantung pada ketepatan waktu pelaksanaan berdasarkan estimasi durasi proyek (Dursun \& Stoy, 2012). Namun, durasi proyek seringkali tidak sesuai dengan prediksi karena disebabkan oleh ketidakpastian sehingga jadwal konstruksi dapat menyimpang dari rencana semula (Baqerin, et al., 2015). Kondisi ini mempersulit penaksir untuk 
memperkirakan durasi secara akurat. Para peneliti menyatakan bahwa perhitungan durasi akhir proyek lebih baik dinyatakan dalam sebuah rentang metode probabilistik daripada 1 angka pasti yang menggunakan metode deterministik karena ketidakpastian yang dapat berasal dari sejumlah sumber yang mungkin dan menyebabkan banyak hambatan terhadap jadwal yang sudah ditentukan (Goldratt, 1997; Isidore, 2001; Herroelen, 2005; Kim \& Reinschmidt, 2009; Anondho, 2018; Barazza, et al., 2004), dengan waktu paling lambat penyelesaian proyek sebagai batas atas dan waktu tercepat penyelesaian proyek sebagai batas bawah.

Salah satu metode yang dapat digunakan untuk menentukan durasi akhir suatu proyek konstruksi adalah metode Earned Value Management (EVM) yang terdiri dari Earned Value, Earned Schedule, dan Earned Duration. Earned Value (EV) merupakan sebuah teknik yang sering digunakan untuk memprediksi durasi proyek. Namun, beberapa peniliti menunjukkan bahwa indikator SPI pada metode EV cenderung memberikan hasil yang kurang akurat ketika proyek mendekati waktu selesai (Kim \& Kim, 2014; Alshaheen, 2018; Anondho, et al., 2018). Metode EVM yang lain adalah Earned Duration (ED) yang dikenalkan oleh Jacob (2003) dan dikembangkan oleh Khamooshi dan Golafshani (2013) untuk memprediksi durasi proyek dengan menggunakan indikator waktu dan mengeliminasi semua indikator biaya. Namun, para peneliti menunjukkan adanya kesulitan dalam mengerti beberapa konsep ED dan kesulitan dalam mengumpulkan data tiap progres pekerjaan karena data tersebut cenderung bersifat rahasia (Vanhoucke, et al., 2015; Anondho, 2018). Earned Schedule (ES) merupakan metode prediksi durasi proyek yang dikembangkan dari EV oleh Walter Lipke sejak tahun 2003 dan dinilai mampu mengatasi kekurangan EV dengan menciptakan indikator SPI berbasis waktu (Narbaev dan Marco, 2014).

Karena perhitungan estimasi durasi proyek dengan menggunakan metode EV dianggap kurang relevan dan perhitungan estimasi dengan metode ED dianggap terlalu rumit, maka penelitian ini menggunakan metode ES untuk melakukan perhitungan estimasi durasi proyek probabilistik pada proyek konstruksi di daerah Jakarta.

\section{Tujuan Penelitian}

Berdasarkan latar belakang dan permasalahan yang sudah disebutkan, tujuan penelitian ini adalah melakukan validasi nilai prediksi durasi pesimistik (batas atas) dan durasi optimistik (batas bawah) proyek yang sedang berjalan yang dihitung dengan metode Earned Schedule.

\section{METODE PENELITIAN}

\section{Metode Pengumpulan Data}

Data yang dikumpulkan adalah 43 data kurva S proyek gedung konstruksi bertingkat yang sedang berjalan dan 35 data durasi nyata proyek yang sudah selesai di daerah Jakarta. Data proyek yang sedang berjalan diperuntukan untuk perhitungan estimasi atau prediksi durasi akhir serta perhitungan rata-rata batas atas dan batas bawah proyek tersebut. Data durasi nyata proyek yang sudah selesai diperuntukan untuk validasi hasil perhitungan batas atas dan batas bawah prediksi durasi proyek yang sedang berjalan. Selain studi lapangan, dilakukan juga studi literatur dari buku dan jurnal mengenai durasi probabilistik dan metode ES untuk guna mengkaji dan menganalisis data yang telah diperoleh. 


\section{Durasi Probabilistik}

Terdapat dua model dalam penentuan estimasi durasi proyek, yaitu deterministik dan probablistik. Deterministik adalah kondisi dimana nilai variabel atau perubahan nilainya bersifat dapat diprediksi dengan kepastian, sedangkan probabilistik adalah suatu keadaan persediaan yang mengandung ketidakpastian (Bahagia, 2006). Estimasi menggunakan perhitungan probabilistik dinilai lebih cocok mengingat durasi proyek memiliki sifat ketidakpastian.

Dengan menggunakan pendekatan PERT, terdapat angka-angka estimasi yang berperan sebagai batasan waktu pelaksanaan kegiatan proyek yaitu sebagai berikut.

- Waktu Optimistik atau Optimistic Duration Time (a)

Waktu optimistik adalah waktu tersingkat untuk menyelesaikan kegiatan apabila segala sesuatu berjalan dengan mulus.

- Waktu Pesimistik atau Pessimistic Duration Time (b)

Waktu pesimistik adalah waktu paling lama untuk menyelesaikan kegiatan apabila segala sesuatu tidak baik dan kurang mendukung.

Perhitungan batas atas dan batas bawah untuk jumlah data $n>30$ dengan standar deviasi populasi diketahui adalah sebagai berikut.

$$
\bar{x} \pm Z_{\alpha / 2} \frac{\sigma}{\sqrt{n}}
$$

dengan $\bar{x}=$ rata-rata nilai sampel, $Z_{\alpha / 2}=$ nilai $Z$ berdasarkan tingkat kepercayaan, $\sigma=$ standar deviasi sampel dan $\mathrm{n}=$ jumlah sampel.

Batas atas dan batas bawah diasumsikan berada dalam rentang 95\% sesuai dengan konsep probabilitas dalam statistik yang bisa disebut sebagai waktu optimistik atau waktu tercepat dan waktu pesimistik atau waktu paling lama penyelesaian proyek.

\section{Metode Analisis Data}

Analisis data proyek yang sedang berjalan dimulai dengan perhitungan ES, perhitungan prediksi durasi akhir, penyelarasan satuan waktu dan besaran, serta perhitungan batas atas dan batas bawah prediksi durasi.

\section{Earned Schedule}

Metode Earned Schedule (ES) merupakan metode pengembangan EVM yang dikembangkan oleh Lipke sejak 2003. Metode ini memberikan hasil yang lebih dapat dipercaya dalam memperkirakan durasi akhir suatu proyek (Lipke, et al., 2009). Konsep dasar metode ini adalah untuk menentukan letak waktu progres aktual (kurva EV) terhadap progres rencana yang seharusnya terjadi (kurva PV) dengan cara memplot kurva EV pada waktu aktual ke kurva PV (Gambar 1). Titik proyeksi yang diperoleh dari hasil plotting merupakan nilai ES. 


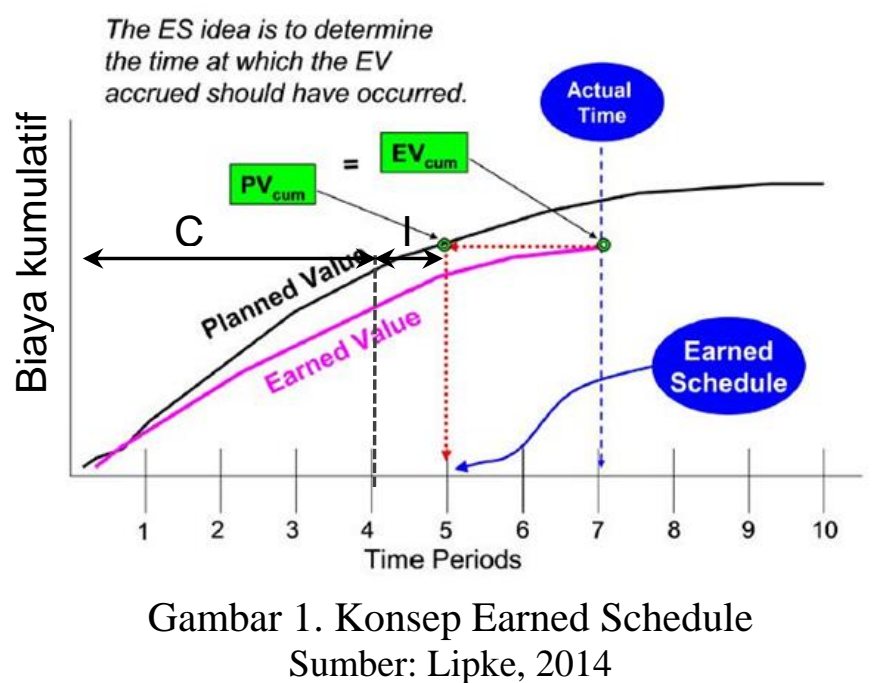

ES dapat dihitung dengan menggunakan dua komponen utama yaitu, C dan I. Dimana $\mathrm{C}$ adalah nilai periode yang sudah terlewati dan I dapat dihitung menggunakan rumus berikut.

$$
\mathrm{I}=(\mathrm{EV}-\mathrm{PV}) /\left(\mathrm{PV}_{\mathrm{C}+1}-\mathrm{PV}\right)
$$

dengan $\mathrm{EV}=$ Earned Value atau nilai yang diterima dari penyelesaian pekerjaan selama periode waktu tertentu dan PV = Planned Value pada titik yang ditinjau atau anggaran biaya yang dialokasikan berdasarkan rencana kerja yang telah disusun terhadap waktu tertentu, dan $\mathrm{PV}_{\mathrm{C}+1}=$ Planned Value pada satu titik setelah titik yang ditinjau.

Selanjutnya ES dapat dihitung dengan rumus berikut.

$$
\mathrm{ES}=\mathrm{C}+\mathrm{I}
$$

Kemudian dihitung SPI(t) yang menunjukkan seberapa efisien waktu yang telah digunakan. Rasio SPI(t) dengan nilai kurang dari 1 mengindikasikan bahwa proyek akan diselesaikan lebih lambat dari rencana awal.

$$
\mathrm{SPI}(\mathrm{t})=\frac{\mathrm{ES}}{\mathrm{AT}}
$$

dengan $\mathrm{ES}=$ nilai $\mathrm{ES}$ yang sudah dihitung dan $\mathrm{AT}=$ waktu aktual.

Prediksi durasi akhir proyek dapat dihitung menggunakan rumus berikut.

$$
\mathrm{EAC}(\mathrm{t})=\mathrm{AT}+\frac{\mathrm{PD}-\mathrm{ES}}{\mathrm{SPI}(\mathrm{t})}
$$

dengan $\mathrm{PD}=$ durasi rencana.

\begin{tabular}{|c|c|c|c|c|c|c|c|c|c|c|}
\hline Proyek & $\begin{array}{c}\text { Progres } \\
\text { Aktual } \\
\text { (EV) }\end{array}$ & $\begin{array}{c}\text { Kinerja } \\
\text { Durasi } \\
(\mathrm{PV})\end{array}$ & $\begin{array}{c}\text { Kinerja } \\
\text { Durasi +1 } \\
(\mathrm{PVC}+1)\end{array}$ & $\mathrm{C}$ & I & ES & $\begin{array}{c}\text { Durasi } \\
\text { Realisasi }\end{array}$ & SPI & $\begin{array}{l}\text { Durasi } \\
\text { Nyata }\end{array}$ & EAC \\
\hline \multicolumn{11}{|l|}{$\mathrm{P} 1_{1}$} \\
\hline \multicolumn{11}{|l|}{$\ldots$} \\
\hline $\mathrm{P} 1_{\mathrm{n}}$ & & & & & & & & & & \\
\hline
\end{tabular}

Penyajian analisis data prediksi durasi akhir proyek yang sedang berjalan dengan metode ES dituangkan dalam bentuk Tabel 1.

Tabel 1. Bentuk tabel data prediksi durasi akhir proyek yang sedang berjalan 
Untuk perhitungan batas atas dan batas bawah prediksi durasi digunakan Tabel 2.

Tabel 2. Bentuk tabel perhitungan batas atas dan batas bawah prediksi durasi

\begin{tabular}{cccccccc}
\hline No & Proyek & $\begin{array}{c}\text { Luas } \\
\text { Lantai } \\
\left(\mathrm{m}^{2}\right)\end{array}$ & EAC & EAC $/ \mathrm{m}^{2}$ & $\begin{array}{c}\text { Satuan } \\
\text { Waktu }\end{array}$ & $\begin{array}{c}\mathrm{EAC} / \mathrm{m}^{2} \\
(\mathrm{minggu})\end{array}$ & \multicolumn{2}{c}{$\begin{array}{c}\text { Interval Rata-rata }\left(\mathrm{minggu} / \mathrm{m}^{2}\right) \\
\text { Pesimistik }\end{array}$} & $\begin{array}{c}\text { Durasi } \\
\text { Optimistik }\end{array}$ \\
\hline $\mathrm{P} 1_{1}$ & & & & & \\
\hline$\ldots$ & & & & \\
\hline $\mathrm{P} 1_{\mathrm{n}}$ & & & & \\
\hline
\end{tabular}

Analisis data proyek yang sudah selesai dimulai dengan penyelarasan satuan waktu durasi nyata, perhitungan rata-rata durasi nyata, serta perhitungan batas atas dan batas bawah durasi nyata. Penyajian data durasi nyata/realisasi proyek yang sudah selesai dituangkan dalam bentuk Tabel 3.

Tabel 3. Bentuk tabel data durasi nyata proyek yang sudah selesai

\begin{tabular}{|c|c|c|c|c|c|c|c|c|}
\hline \multirow[b]{2}{*}{ No } & \multirow[b]{2}{*}{ Proyek } & \multirow{2}{*}{$\begin{array}{l}\text { Luas } \\
\text { Lantai } \\
\left(\mathrm{m}^{2}\right)\end{array}$} & \multirow[b]{2}{*}{$\begin{array}{c}\text { Durasi } \\
\text { Realisasi }\end{array}$} & \multirow[b]{2}{*}{$\begin{array}{l}\text { Satuan } \\
\text { Waktu }\end{array}$} & \multirow[b]{2}{*}{$\begin{array}{c}\text { Durasi } \\
\text { Realisasi } / \mathrm{m}^{2}\end{array}$} & \multirow{2}{*}{$\begin{array}{c}\text { Durasi } \\
\text { Realisasi } \\
(\text { minggu/m²) }\end{array}$} & \multicolumn{2}{|c|}{ Interval Rata-rata $\left(\mathrm{minggu} / \mathrm{m}^{2}\right)$} \\
\hline & & & & & & & $\begin{array}{c}\text { Durasi } \\
\text { Pesimistik }\end{array}$ & $\begin{array}{c}\text { Durasi } \\
\text { Optimistik }\end{array}$ \\
\hline \multicolumn{9}{|l|}{$\mathrm{P} 2_{1}$} \\
\hline$\ldots$ & & & & & & & & \\
\hline $\mathrm{P} 2_{\mathrm{n}}$ & & & & & & & & \\
\hline
\end{tabular}

Kemudian dilakukan validasi antara perhitungan batas atas prediksi durasi dengan rata-rata durasi nyata, dan validasi antara batas bawah prediksi durasi dengan rata-rata durasi nyata. Dengan tingkat kepercayaan $95 \%$, jika perhitungan prediksi dinyatakan valid maka nilai tersebut dapat digunakan sebagai batas atas dan/atau batas bawah penelitian ini. Namun jika dinyatakan tidak valid, maka diambil nilai batas atas atau batas bawah durasi nyata proyek yang sudah selesai. Data dihitung dengan bantuan program Microsoft Excel.

\section{Validasi menggunakan Uji Hipotesis Rata-rata Sampel Ganda}

Salah satu teknik validasi adalah uji statistik yang penerapannya tergantung pada jenis data yang tersedia. Membandingkan dua kelompok sampel dapat dilakukan dengan validasi menggunakan uji hipotesis rata-rata kedua kelompok sampel. Uji hipotesis rata-rata sampel ganda dengan jumlah sampel > 30 dan data bersifat independen dapat dilakukan dengan langkah-langkah sebagai berikut.

1. Pernyataan Hipotesis Awal dan Hipotesis Alteratif

Dalam uji ini hipotesis awalnya yaitu rata-rata perbedaan adalah nol. Sedangkan hipotesis alternatifnya adalah terdapat nilai rata-rata perbedaan.

Jadi: $\quad \mathrm{H} 0: \mu 1=\mu 2$

$$
\mathrm{H} 1: \mu 1 \neq \mu 2 \rightarrow \text { uji dua-ujung }
$$

2. Pemilihan Tingkat Keyakinan $(\alpha)$

Batas atas dan batas bawah diasumsikan berada dalam rentang 95\% sehingga taraf nyata $(\alpha)=$ 0.05 .

3. Penentuan Distribusi Pengujian yang Digunakan

Digunakan uji Z karena jumlah sampel > 30 dan kedua data bersifat independen. 


\section{Pendefinisian Daerah-daerah Penolakan atau Kritis}

Daerah keputusan yang digunakan adalah daerah keputusan untuk dua arah. Daerah penolakan $\mathrm{H}_{0}$ terdapat pada dua sisi yaitu di ekor sebelah kiri dan sebelah kanan. Karena daerah penolakan ada dua, maka taraf nyata adalah $\alpha / 2$.

5. Pernyataan Aturan Keputusan (Decision Rule)

Dengan melihat letak nilai uji statistik pada daerah keputusan, dapat diambil kesimpulan yaitu tolak $\mathrm{H}_{0}$ dan terima $\mathrm{H}_{1}$ jika $\mathrm{RU}<-\mathrm{Z} \alpha / 2$ atau $\mathrm{RU}>\mathrm{Z} \alpha / 2$. Jika tidak demikian terima $\mathrm{H}_{0}$.

6. Perhitungan Rasio Uji (RU)

Nilai rasio uji digunakan untuk menentukan apakah sampel yang diuji berada di dalam penerimaan atau penolakan hipotesis nol. Rasio uji dihitung dengan rumus berikut.

$$
\begin{aligned}
\sigma_{\bar{x}_{1}-\bar{x}_{2}} & =\sqrt{\frac{\sigma_{1}^{2}}{n_{1}}+\frac{\sigma_{2}^{2}}{n_{2}}} \\
\mathrm{RUZ} & =\frac{\bar{x}_{1}-\bar{x}_{2}}{\sigma_{\bar{x}_{1}}-\bar{x}_{2}}
\end{aligned}
$$

dengan $\mathrm{RUz}=$ rasio uji pada uji $\mathrm{Z}, \bar{x}_{1}=$ rata-rata batas atas/bawah durasi proyek yang sedang berjalan, $\bar{x}_{2}=$ rata-rata durasi proyek yang sudah selesai, $\sigma_{1}=$ standar deviasi batas atas/bawah durasi proyek yang sedang berjalan, $\sigma_{2}=$ standar deviasi durasi proyek yang sudah selesai, $\mathrm{n}_{1}=$ jumlah data proyek yang sedang berjalan, dan $n_{2}=$ jumlah data proyek yang sudah selesai.

\section{Pengambilan Keputusan secara Statistik}

Jika nilai rasio uji berada di daerah penerimaan maka hipotesis nol diterima yang berarti hasil dinyatakan valid. Hal ini berarti tidak terdapat perbedaan antara kedua sampel. Sedangkan jika berada di daerah penolakan maka hipotesis nol ditolak yang berarti hasil dinyatakan tidak valid. Hal ini berarti terdapat perbedaan antara kedua sampel.

\section{HASIL DAN PEMBAHASAN}

\section{Hasil Perhitungan Prediksi Durasi dengan Metode ES}

Dengan menggunakan 43 data kurva S proyek yang sedang berjalan, dapat dihitung nilai ES dari tiap proyek. Dalam kurva S 1 proyek bisa didapat banyak nilai ES. Setelah diperoleh nilai ES selanjutnya dihitung SPI dan durasi akhir proyek (EAC).

Selanjutnya perlu dilakukan penyelarasan satuan waktu menjadi minggu karena sebagian data proyek diatas menggunakan minggu sebagai satuan waktu dan sebagian proyek lainnya menggunakan bulan. Selain itu, data proyek yang diperoleh memiliki luas lantai yang berbedabeda sehingga perlu dilakukan penyelarasan dengan membagi nilai EAC dengan luas lantai proyek masing-masing. Setelah dilakukan penyelarasan EAC, dihitung batas atas dan batas bawah prediksi durasi menggunakan data durasi akhir tiap proyek dan standar deviasi. Nilai $\mathrm{Z}$ sebesar \pm 1.96 karena daerah keputusan yang digunakan adalah 2 arah sehingga $Z_{\alpha / 2}=0.025$.

Dari hasil perhitungan diperoleh rata-rata batas atas prediksi durasi adalah sebesar 0.0025 $\mathrm{minggu} / \mathrm{m}^{2}$ dan rata-rata batas bawah adalah sebesar $0.0018 \mathrm{minggu} / \mathrm{m}^{2}$.

\section{Perhitungan Rata-rata serta Batas Atas dan Batas Bawah Durasi Nyata Proyek}

Data durasi nyata 35 proyek yang sudah selesai memiliki satuan waktu yang berbeda, sehingga perlu dilakukan penyelarasan satuan waktu menjadi minggu terlebih dahulu sebelum dihitung rata-rata durasinya. Kemudian dihitung juga batas atas dan batas bawah durasi nyata yang akan digunakan jika rata-rata batas atas dan/atau batas bawah prediksi durasi dinyatakan tidak valid.

Dari hasil perhitungan didapat rata-rata durasi nyata sebesar $0.0026 \mathrm{minggu} / \mathrm{m}^{2}$ dengan rata-rata batas atas adalah sebesar $0.0032 \mathrm{minggu} / \mathrm{m}^{2}$ dan rata-rata batas bawah adalah sebesar 0.0020 minggu $/ \mathrm{m}^{2}$. 


\section{Validasi Rata-rata Batas Atas dan Batas Bawah Prediksi Durasi dengan Rata-rata Durasi Nyata}

Dilakukan validasi menggunakan uji hipotesis rata-rata sampel ganda dengan ketentuan jika nilai RUz berada dalam rentang $-1.96<\mathrm{RUz}<1.96$ (valid), maka nilai batas atas/bawah prediksi durasi dapat ditetapkan sebagai nilai batas atas/bawah penelitian ini. Namun, jika RUz berada diluar rentang tersebut (tidak valid), maka diambil nilai batas atas/bawah durasi nyata sebagai nilai batas atas penelitian.

Dari hasil perhitungan batas atas prediksi durasi sebesar $0.0025 \mathrm{minggu} / \mathrm{m}^{2}$ (standar deviasi 0.001275 ) dengan nilai rata-rata durasi nyata sebesar $0.0026 \mathrm{minggu} / \mathrm{m}^{2}$ didapat nilai $\mathrm{RUz}$ sebesar -0.3217 . Nilai ini masuk dalam rentang $-1.96<\mathrm{RUz}<1.96$, sehingga hasil dinyatakan valid. Maka, nilai batas atas prediksi durasi dapat ditetapkan sebagai nilai batas atas penelitian ini.

Dari hasil perhitungan batas bawah prediksi durasi sebesar $0.0018 \mathrm{minggu} / \mathrm{m}^{2}$ (standar deviasi 0.001275 ) dengan nilai rata-rata durasi nyata sebesar $0.0026 \mathrm{minggu} / \mathrm{m}^{2}$ didapat nilai $\mathrm{RUz}$ sebesar -2.4080. Nilai ini berada diluar rentang RUz $<-1.96$, sehingga hasil dinyatakan tidak valid. Maka, diambil nilai batas bawah durasi nyata sebagai nilai batas bawah penelitian ini.

\section{KESIMPULAN}

\section{Kesimpulan}

Pengumpulan data kurva $\mathrm{S}$ proyek yang sedang berjalan cukup dapat dipergunakan untuk perhitungan prediksi durasi proyek dengan metode ES. Dari hasil perhitungan dan validasi dapat disimpulkan bahwa batas atas prediksi durasi dinyatakan valid dan batas bawah dinyatakan tidak valid dengan nilai batas atas sebesar $0.0025 \mathrm{minggu} / \mathrm{m}^{2}$ dan nilai batas bawah sebesar 0.0020 $\operatorname{minggu} / \mathrm{m}^{2}$.

\section{Saran}

1. Penelitian selanjutnya dapat memperluas batasan dengan mengumpulkan data proyek selain gedung bertingkat serta dapat memperluas daerah pengambilan data proyek.

2. Metode perhitungan durasi akhir proyek dapat diperluas dengan menggunakan metode prediksi durasi yang lain seperti Gantt Chart dan Performance Intensity.

3. Pengembangan penelitian selanjutnya dapat diperdalam dengan penambahan metode yang lain seperti studi kasus mengingat penelitian ini hanya menggunakan studi literatur, studi lapangan pengambilan data kurva $S$ dan perumusan empiris pada pengolahan data.

\section{REFERENSI}

Alshaheen, A. (2018). Forecasting Project Completion Date Using Earned Schedule and Primavera. The Measurable News.

Anondho, B., Latief, Y., \& M., K. (2018). Probabilistic Duration Calculation Based on Earned Schedule Approach. International Journal of Civil Engineering and Technology (IJCIET), 9(5).

Anondho, B. (2018) Pengembangan Model Prediksi Durasi Probabilistik Proyek Pembangunan Gedung Bertingkat Tinggi Berbasis Faktor Pengaruh Eksternal Terukur. Disertasi, Universitas Indonesia. 
Bahagia, S. N. (2006). Sistem Inventori. Bantung: ITB.

Baqerin, M. H., Shafani, Y., \& Kashani, H. (2015). Application of Weibull Analysis to Evaluate and Forecast Schedule Performance in Repetitive Projects. Journal of Construction Engineering and Management, 142(2).

Barazza, G. M., Back, W. E., \& Mata, F. (2004). Probabilistic Forecasting of Project Performance Using Stochastic S Curves. Journal of Construction Engineering and Management, 130(1).

Dursun, O., \& Stoy, C. (2012). Determinants of Construction Duration of Building Projects in Germany. Engineering, Construction and Architectural Management, 19.

Goldratt, E. M. (1997). Critical Chain. Great Barrington, MA: North River Press

Herroelen, W., \& Leus, R. (2005). Project scheduling under uncertainty: Survey and research potentials. European Journal of Operational Research, 165, 289-306.

Isidore, L. J., \& Back, W. E. (2001). Probabilistic Optimal-Cost Scheduling. Journal of Construction Engineering and Management, 127(6).

Jacob, D. S. (2003). Forecasting Project Schedule Completion with Earned Value Metrics. The Measurable News.

Khamooshi, H., \& Golafshani, H. (2013). EDM: Earned Duration Management, A New Approach to Schedule Performance Management and Measurement. International Journal of Project Management, 32.

Kim, B. C., \& Kim, H. J. (2014). Sensitivity of Earned Value Schedule Forecasting to S-Curve Patterns. Journal of Construction Engineering and Management, 140(7).

Kim, B. C., \& Reinschmidt, K. F. (2009). Probabilistic Forecasting of Project Duration Using Bayesian Inference and The Beta Distribution. Journal of Construction Engineering and Management, 135(3).

Lipke, W. (2014). Ten Years After. PM World Journal, 3(1).

Lipke, W., Zwikael, O., Henderson, K., \& Anbari, F. (2009). Prediction of Project Outcome: The Application of Statistical Methods to Earned Value Management and Earned Schedule Performance Indexes. International Journal of Project Management, 27(4).

Narbaev, T., \& Marco, A. D. (2014). Combination of Growth Model and Earned Schedule to Forecast Project Cost at Completion. Journal of Construction Engineering and Management, 140(1). 